\title{
Corrective Action Number
}

National Cancer Institute

\section{Source}

National Cancer Institute. Corrective Action Number. NCI Thesaurus. Code C53619.

Number assigned to an action reported to FDA under 21 USC 260(f). 